\title{
THE GRAVITY AND PROTEIN METABOLISM OF SKELETAL MUSCLES IN JAPANESE QUAIL. IN VIVO AND IN VITRO COMPARISON
}

\author{
J. JANKELA, M. BARANOVSKÁ \\ Institute of Animal Biochemistry and Genetics, SAS, 90028 Ivanka pri Dunaji, Slovak Republic
}

Received April 18, 1995

Accepted June 6, 1996

\begin{abstract}
Janke la J., M. Baranovská: The Gravity and Protein Metabolism of Skeletal Muscles in Japanese Quail. In vivo and in vitro Comparison. Acta vet. Brno 1996, 65: 77-81.

The aim of the experiment was to observe the effect of increased gravitational field $(2 \mathrm{~g})$ on the synthesis and degradation rates of skeletal muscles proteins in Japanese quail. The observations in vivo were compared with results obtained on the isolated muscles.

The rates of synthesis and degradation of mixed proteins in $\mathrm{m}$. biceps brachii and $\mathrm{m}$. iliotibialis anterior were estimated. It was shown, that the protein synthesis rates only in in vivo experiment were affected. A decrease of protein degradation rates in both conditions were observed.
\end{abstract}

$2 \mathrm{~g}$ hypergravity, protein synthesis and degradative rates, effect in vivo, in vitro

For determination of the capacity of muscles to cope with the load of gravitational stress it is important to understand the influence of altered gravity. Our earlier results ( $\mathrm{G}$ a ž o et al. 1988; J a n k e l a et al. 1991) confirmed that altered gravity caused changes in muscle mass connected with changes in protein level and composition. It is anticipated that muscle growth or atrophy is regulated by the changes in protein synthesis or degradation (V a n d e $\mathrm{n}$ b u r g h 1987). We paid attention to quantification of these processes. To eliminate the possible effect of neurohumoral mechanisms, the observations in vivo were compared with results of experiment in which isolated muscles were used.

\section{In vivo experiment}

\section{Materials and Methods}

42 days old japanese quail - cockerels were used. The control birds were kept under normal husbandry conditions ( 24 hours lighting, ambient temperature $21^{\circ} \mathrm{C}$, commercial mash ad libitum). The experimental treatment of increased gravitational field $(2 \mathrm{~g})$ was administered for 144 hours continually by means of centrifuge. Parameters are given in G ažo et al. (1988). During the centrifugation the feed supply, lighting and temperature were the same as in the control group. Centrifugation was interrupted only for a few minutes one hour before finishing the centrifugation, the label $\mathrm{C}^{\mathrm{i} 4}$ arginine was peritoneally injected. Breast (m. supracoracoides) and thigh (m. superficialis fibularis) muscles were removed and analysed for protein (Low r y et al. 1957), RNA and DNA ( $\mathrm{C}$ a n e v and Mark ov 1960) contents. The parts of muscles were homogenised in 10\% trichloroacetic acid and the sediments were hydrolysed. In supernatants as in hydrolysates the arginine concentration and its radioactivity after thin layer chromatography were estimated. The arginine measurement was according the method of Sakaguchi (Devenyi and Gergely 1974). The radioactivity was measured by means of Packard TriCarb liquid scintillation system.

\section{In vitro experiment}

The wing (m. biceps brachii) and tight (m. iliotibialis anterior) muscles of 42 days old Japanese quail-cockerels, were incubated in the Krebs-Henseleit solution bubled with carbon dioxide - oxygene mixture and centrifuged to $2 \mathrm{~g}$ for one hour. For synthetic rate measurement the $\mathrm{C}^{14}$ arginine was added into the solution. The muscles were analysed for arginine concentration and radioactivity by the methods mentioned above. For the determination of the degradative rate the inhibitor of protein synthesis (actinomycine) was added into incubation solution. The estimation of degradative rate was established on the measurement of loosed thyrosine in that solution. The thyrosine measurement was according the method of Udenfriend and Cooper (1952).

The determination of protein synthesis rates were based on the calculations of the specific activities of protein bound and free arginine, in breast and thigh muscle in first experiment or in isolated wing and thigh muscle in the second. Protein degradation was calculated as a difference between synthetic and growth rates ( $\mathrm{M}$ u r a m a t $\mathrm{s}$ u et al. 1985) in in vivo experiment. In isolated muscles the determination of degradative rate was established on the measurement of loosed thyrosine after inhibition of protein synthesis. 
Results and Discussion

In vivo experiment.
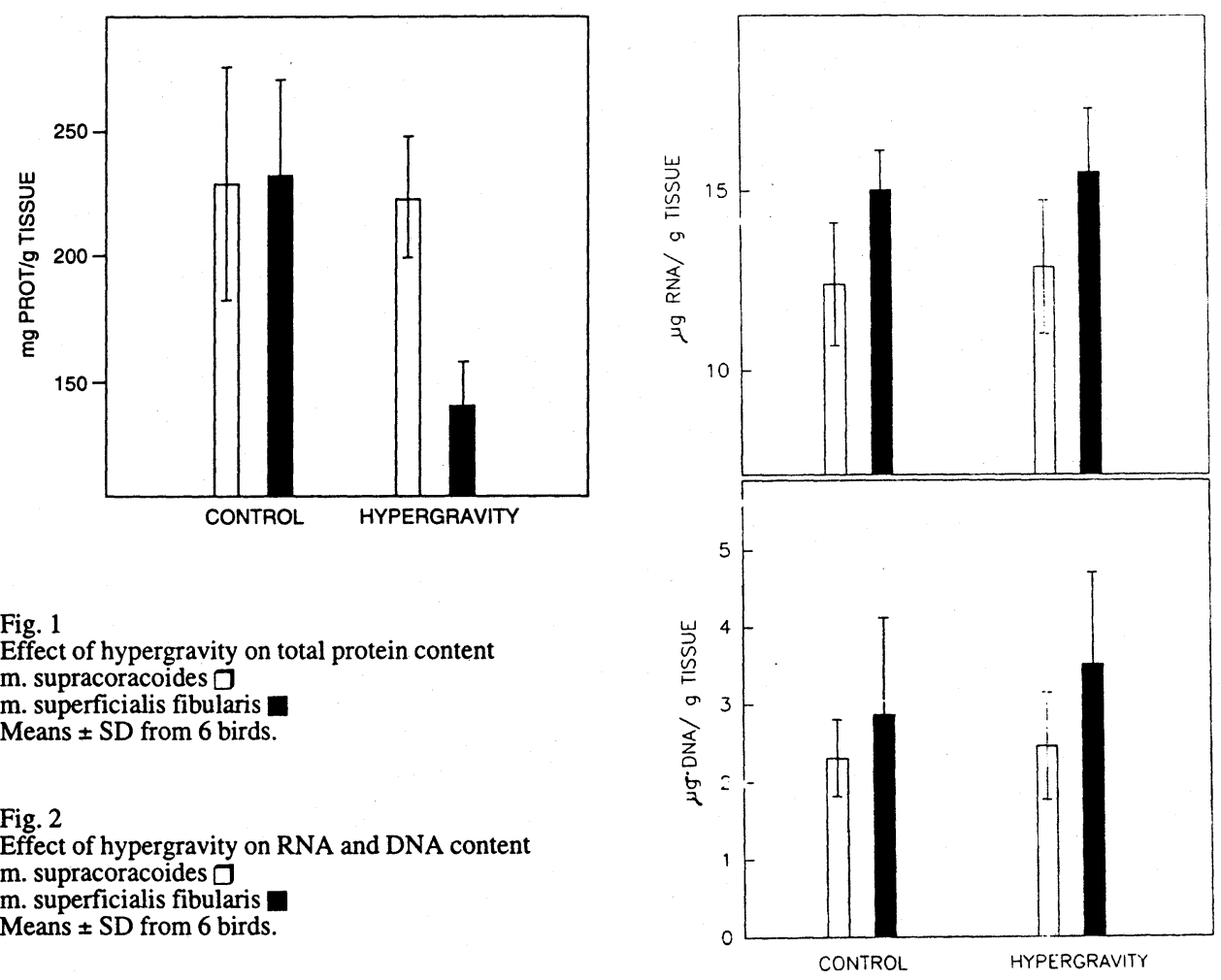

Fig. 1

Effect of hypergravity on total protein content m. supracoracoides $\square$ $\mathrm{m}$. superficialis fibularis Means \pm SD from 6 birds.

Fig. 2

Effect of hypergravity on RNA and DNA content m. supracoracoides $\square$ m. superficialis fibularis Means \pm SD from 6 birds.

Total protein content was changed, particularly in breast muscle (Fig. 1). Hypergravity provoked significant $(\mathrm{P}<0.01)$ decrease of total proteins in $\mathrm{m}$. supracoracoides. The change in protein content of $\mathrm{m}$. superficialis fibularis was not so intensive. Experimental treatment only slightly diminuted this parameter. The characterisation of nucleic acids equipment is shown in the Fig. 2. The nucleic acids (RNA, DNA) contents in both muscles were not significantly affected by treatment employed. However the DNA content tended to increase in $\mathrm{m}$. supracoracoides. In such case RNA/DNA ratios shown slight shifts to lower values in experimental group. Hypergravity reduced significantly fractional growth rate (FGR) (Fig. 3) mainly in m. supracoracoides. Absolute values of growth rates expressed as amount of proteins accumulated in tissue per day were not so apparent and showed any significant differences. The fractional synthesis rate (FSR) was influenced, too (Fig. 4). Particularly in $\mathrm{m}$. supracoracoides was significantly $(\mathrm{P}<0.01)$ depressed in contrast to control group. In $\mathrm{m}$. superficialis of animals exposed to hypergravity the synthesis rate only tended to decrease. The highest ASR in $\mathrm{m}$. supracoracoides was reached in control, the value of which was significantly higher from values in birds in hypergravity. The degradative processes i. e. FDR shown the similar results (Fig. 5), so that the FSR/FDR ratio remains approximately the same. Although any substantial changes in DNA or RNA contents were registered, the significant decreases $(\mathrm{P}<0.01)$ of total protein/DNA ratio or recalculation of $\mathrm{g}$ daily syntheti- 


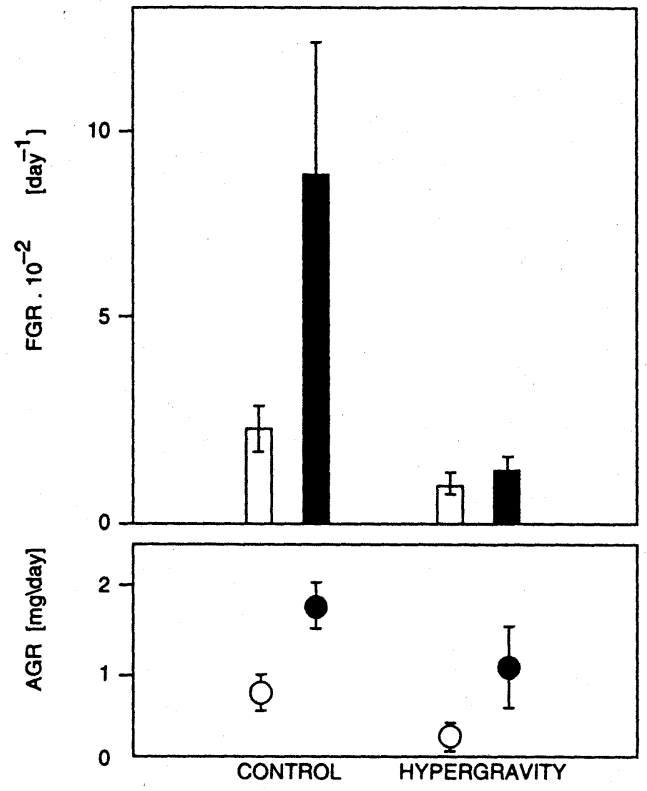

Fig. 3

Effect of hypergravity on fractional (FGR) and absolute (AGR) growth rate m. supracoracoides $\square$ $\mathrm{m}$. superficialis fibularis Means \pm SD from 6 birds.

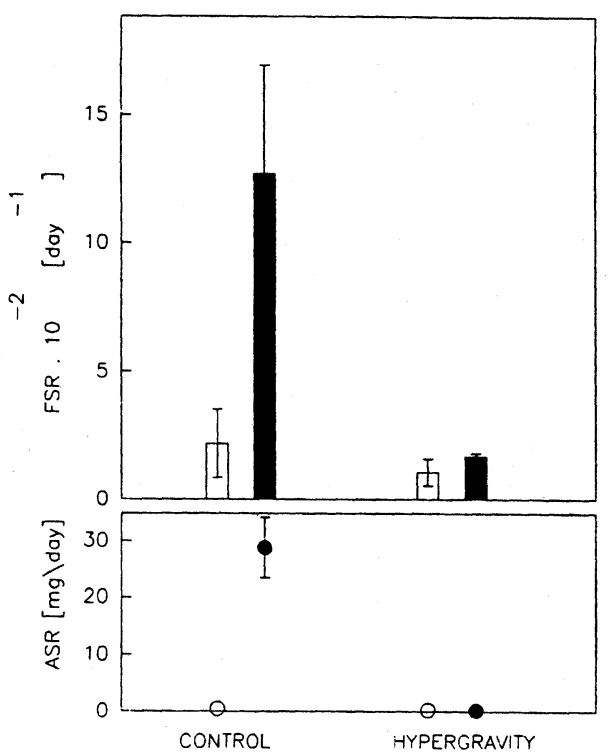

Fig. 4

Effect of hypergravity on fractional (FSR) and absolute (ASR) synthesis rate

m. supracoracoides $\square$

$\mathrm{m}$. superficialis fibularis

Means \pm SD from 6 birds.

sed protein (ASR) per $\mathrm{g}$ NA allow to say that hypergravity provokes in $\mathrm{m}$. supracoracoides two effects:

- the decrease of amount of protein per cell

- the diminution of protein synthesis at both transcription and translation levels.

\section{In vitro experime n $\mathrm{t}$}

The effect of hypergravity on protein content of isolated muscles was not so expressive. The protein content of both examined muscles was decreased, but the differences between experimental and control were not significant. On the contrary to intact animals hypergravity did not effect the protein synthetic rates in the isolated muscles (Fig. 6). The observed trends to diminution were not significant. The rate of protein degradation in isolated muscles was significantly $(\mathrm{P}<0.01)$ depressed in experimental group (Fig. 7).

Muscles are known to be subjected to external mechanical forces which may play important roles in muscle metabolism and growth. These forces control skeletal muscle growth or atrophy by regulating the rates of total protein synthesis and degradation ( $\mathrm{V}$ a n d e $\mathrm{n} \mathrm{bu} \mathrm{r} \mathrm{g} \mathrm{1987}$ ). The increase in functional demands causes a rapid increase in metabolism of energy sources (B a r n e s 1987) or directly alter the expression fo the genes for proteins (P e r i a s a $\mathrm{m}$ y et al. 1989). The mechanism by which external forces are translated into biochemical alterations in skeletal muscle are unknown. Protein accumulation in muscle of hypergravity exposed Japanese quail is depressed by the diminution of rates of both processes, synthesis and degradation. As the protein synthetic rates in isolated muscles were not influenced, it seems that neurohumoral mechanisms play a main role in the regulation of protein synthesis during hypergravity. The effect of gravity on the protein degradation neeeds further explanation. As the ratio of synt- 


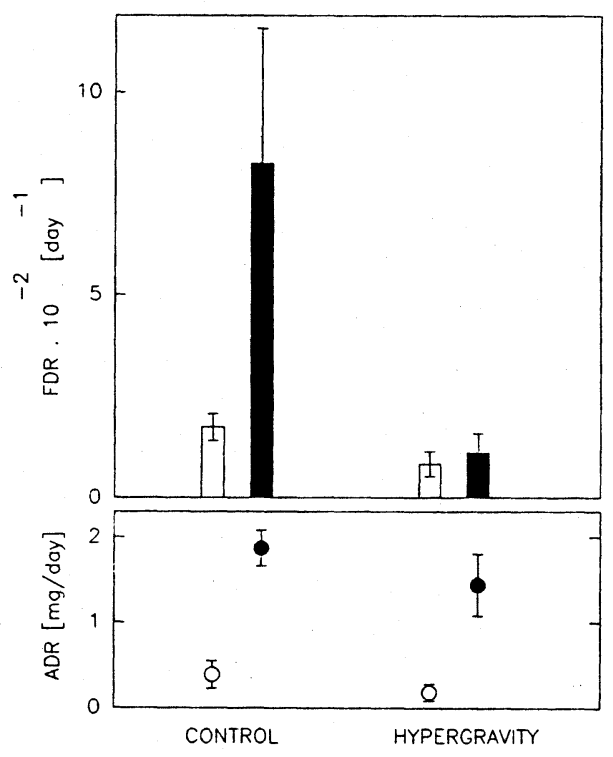

Fig. 5

Effect of hypergravity on fractional (FDR) and absolute (ADR) degradation rate

m. supracoracoides $\square$

$\mathrm{m}$. superficialis fibularis

Means \pm SD from 6 birds.

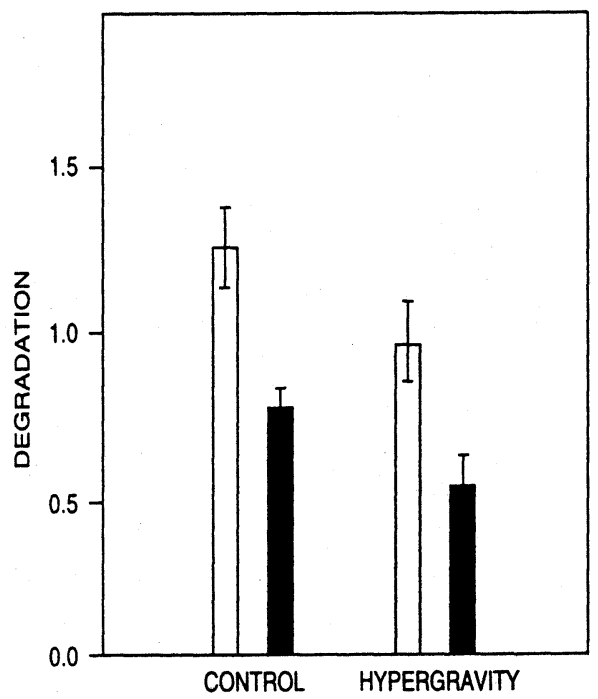

Fig. 7

Effect of hypergravity on degradation rate

m. biceps brachii $\square$

$\mathrm{m}$. iliotibialis anterior

Values are in $\mu \mathrm{g}$ thyrosine per $\mathrm{mg}$ of muscle.

Means \pm SD from 6 birds.

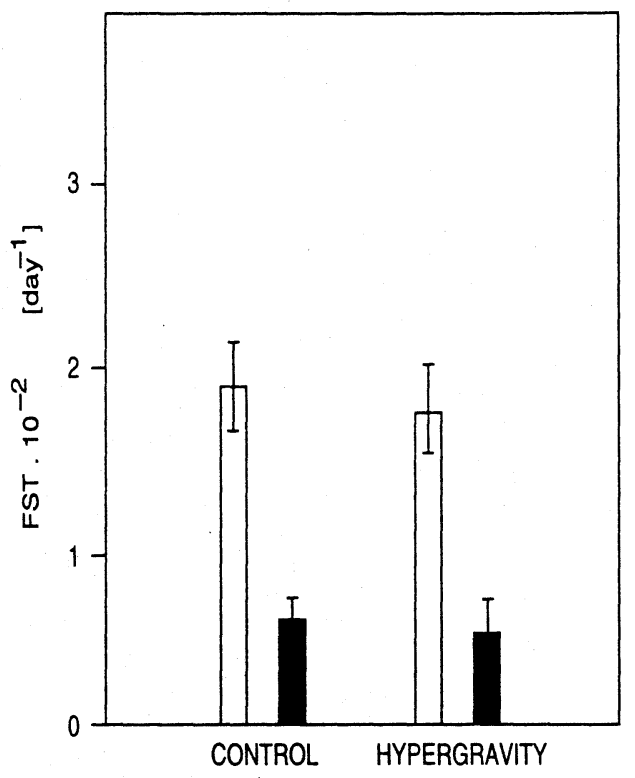

Fig. 6

Effect of hypergravity on fractional synthesis rate (FSR) m. biceps brachii $\square$

$\mathrm{m}$. iliotibialis anterior

Means \pm SD from 6 birds.

hetic and degradative rates in muscles of intact Japanese quail remains approximately the same, proportional mechanisms of regulation evoked by hypergravity may have occurred. The measurement of free thyrosine as the marker of degradative processes in not on the level of methods used in intact animals. Despite that the methods of evaluation of degradation rates in intact animals and in isolated muscles were quite different, the diminutions of observed values were highly significant in both trials. It is obvious that hypergravity strongly depress the protein degradation.

Earlier results ( $\mathrm{G}$ a žo et al. 1988; J a n ke la et al. 1991) confirmed that hypergravity provoked changes in the protein pattern at the level of myofibrillar and sarcoplasmic fractions. The rapid loss of proteins observed in our experiment was connected with the significant decrease of the fractional synthesis rate. This decrease is probably predominantly in the rate of synthesis of noncollagen proteins as turnover of collagen in only $1-2 \%$ /day in skeletal muscles (Reeds et al. 1980). 
Our results show that hypergravity caused rapid decrease of protein synthesis. The explanation of such a phenomenom remains unknown. Though the values of growth, synthesis and degradation rates were different in different groups of animals the FSR/FDR ratio remains approximately the same, which testify to equivalent changes in both synthesis and degradation. Though substantial changes in the nucleic acids content were not recorded, intensive decrease in the protein/DNA ratio with similar decrease in DNA testify that rapid decrease of protein synthesis appears to be iniciated from the efficiences of muscle nuclei for protein synthesis. One main conclusion can be made. The changes are reflected only in $\mathrm{m}$. supracoracoides. This result confirm our previous findings ( $\mathrm{J}$ a n ke la et al. 1991) that muscle susceptibility to external treatment is dependent on the muscle type.

\section{Gravitácia a metabolizmus bielkovín u japonskej prepelice. Porovnanie in vivo a in vitro}

Pokus bol zameraný na sledovanie vplyvu zvýšenej gravitácie $(2 g)$ na rýchlost syntézy a degradácie svalových bielkovín u japonskej prepelice. Porovnali sa výsledky in vivo pokusu s pokusom na izolovaných svaloch.

Boli vyhodnotené rýchlosti syntézy a degradácie zmesných bielkovín $\mathrm{v}$ m. biceps brachii and $\mathrm{m}$. iliotibialis anterior. Ukázalo sa, že rýchlost syntézy bielkovín bola ovplyvnená len $\mathrm{v}$ in vivo pokuse. $\mathrm{V}$ in vivo aj $\mathrm{v}$ in vitro podmienkach bol pozorovaný pokles rýchlosti degradácie.

\section{Гравитация и метаболизм белков японской перепелки. Сопоставление на живом организме и в пробирке}

Эксперимент был направлен на исследование влияния повышенной гравитации (2g) на скорость синтеза и деградации мышечных белков японской перепелки. Сопоставляли результаты эксперимента ин виво с экспериментом на изолированных мышцах.

Проводили оценку скоростей синтеза и деградации смешанных белков m. biceps brachii и $\mathrm{m}$. illio tibialis anterior. Выходит, что скорость синтеза находилась под влиянием лишь в ходе эксперимента на живом организме. В условиях ин виво и ин витро наблюдали понижение скорости деградации.

\section{References}

BARNES, W. S. 1987: Comp. Biochem. Physiol. 86: 229-232

CANEV, R. G., MARKOV, G. G. 1960: Biochimija 25: 151-159

DEVENYI, T., GERGELY, J. 1974: In: Amino Acids, Peptides and Proteins (Akadémiai Kiadó, Budapest), 191

GAŽO, M., BOḊA K., JANKELA, J., VYBOH, P., JURÁNI, M., BARANOVSKÁ, M., STRÁŽNICKÁ, H. 1988:

The Physiologist 31: 138-139

JANKELA, J., BARANOVSKÁ, M., ANTALIKKOVÁ, J. 1991: The Physiologist 34: 132-134

LOWRY, O. H., ROSENBROUGH, N. J., FARR, A. L., RANDALL, R. J. 1951: J. Biol. Chem. 193: 265-275

MURAMATSU, T., SALTER, D. N., COATES, M. E. 1985: Brit. J. Nutr. 54: 131-145

PERIASAMY, M., GREGORY, P., MARTIN, B. J., STIREWALT, W. S. 1989: Biochem. J. 257: 691-698

REEDS, P. J., PALMER, R. M., SMITH, R. H. 1980: Int. J. Biochem. 11: 7-14

UDENFRIEND, S., COOPER, J. R. 1952: J. Biol. Chem. 196: 227

VANDENBURGH, H. H. 1987: Med. Sci. Sports Exer. 19: 142-149 